\title{
Recenzja książki
}

\section{„Harrison. Neurologia w medycynie klinicznej"}

\author{
Hauser S.L. i Josephson S.A. [red.]. \\ Harrison. Neurologia w medycynie klinicznej. \\ Wydanie II polskie. Wydawnictwo Czelej, Lublin 2012
}

„W internecie sprawdzam fakty, ale medycyny uczę się z książek" - ta parafraza opinii z przedmowy do recenzowanej książki trafnie uzasadnia popularność i przydatność niektórych drukowanych podręczników w dobie elektronicznego obiegu informacji. Do książek, po które sięgają kolejne pokolenia lekarzy, z pewnością należy podręcznik chorób wewnętrznych Harrisona (17 wydań). Jego częścia jest „Harrison. Neurologia w medycynie klinicznej” - drugie wydanie polskie tej książki właśnie ukazało się nakładem wydawnictwa Czelej.

Obszerny, 900-stronicowy podręcznik pod redakcją Stephena L. Hausera i Scotta Andrew Josephsona został napisany przez wybitnych znawców tematu (m.in. A.A. Amato, M.J. Aminoffa, R.B. Daroffa, C.W. Olanowa czy S.B. Prusinera). Jest podzielony na sześć części (Wprowadzenie do neurologii, Objawy kliniczne chorób neurologicznych, Choroby ośrodkowego uktadu nerwowego, Zespót przerolektego zmęczenia, Zaburzenia psychiatryczne, Alkoholizm i uzależnienie od leków). Zawiera również materiały i pytania do samodzielnego opracowania, bardzo przydatne w sprawdzaniu nabytej wiedzy.

Podręcznik skierowany jest do lekarza praktyka, przede wszystkim internisty i lekarza rodzinnego. W sposób uporządkowany, przejrzysty i dostosowany do potrzeb odbiorcy dostarcza aktualnych informacji na temat rozpoznawania i leczenia chorób układu nerwowego na podstawie wiarygodnych i aktualnych danych naukowych.

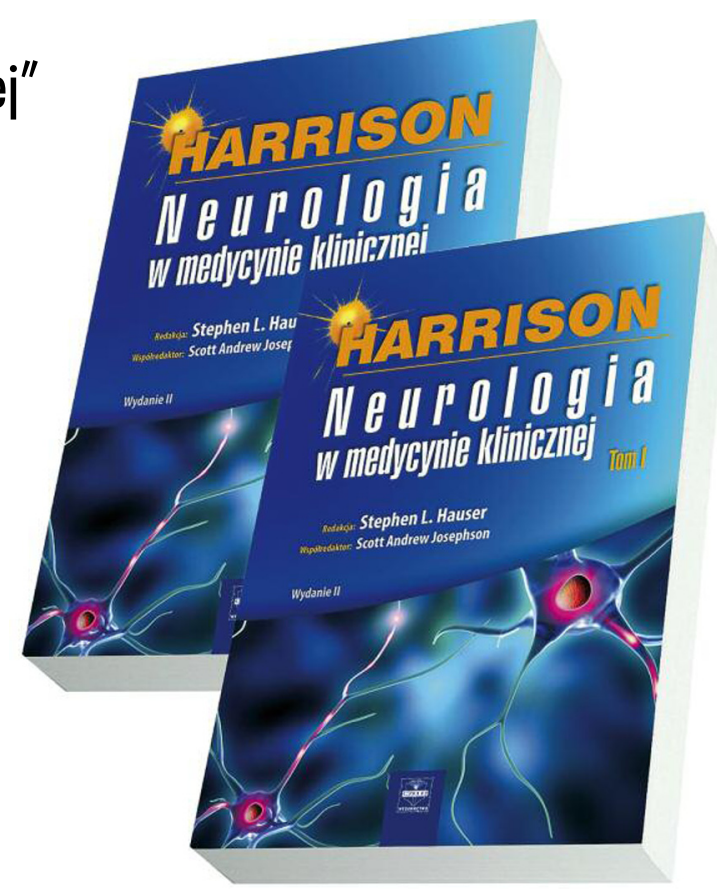

Opracowanie graficzne tekstu, $\mathrm{z}$ wyodrębnionymi na kolorowo fragmentami dotyczącymi postępowania i leczenia, bardzo ułatwia orientację i przyspiesza wyszukiwanie informacji. Jednocześnie można łatwo zagłębić się w tekst i bez znużenia natłokiem danych czytać dłuższe fragmenty.

Podręcznik zawiera liczne tabele, algorytmy postępowania i atlas badań obrazowych. Ryciny znakomicie ilustrują poruszane zagadnienia i są bardzo dobrej jakości.

Lekarze, którzy na co dzień opiekują się zróżnicowaną populacją chorych, $\mathrm{z}$ pewnością docenią szczegółowe omówienie najczęstszych problemów, z którymi zgłaszają się pacjenci (bóle głowy, bóle krzyża, zawroty głowy, utraty przytomności) i zalecenia dotyczące postępowania w najczęstszych przewlekłych chorobach układu nerwowego (choroby naczyniowe i zwyrodnieniowe mózgu). Na uwagę zasługuje również część poświęcona zaburzeniom psychicznym i ich biologicznemu podłożu, która stanowi kolejny dowód na dążenie zespołu autorów do holistycznego ujmowania problemów, z którymi borykają się chorzy, a zatem i ich lekarze.

Bardzo wysoką ocenę podręcznika obniżają nieco tłumaczenie i redakcja polskiego wydania. Czytelnik napotyka liczne anglicyzmy (norepinefryna, kardioemboliczny, radiofrekwencyjna, neurotransmittery, multiple myeloma) i żargon (stenoza, zaślepiona próba); zdarzają się również wyrażenia niezrozumiałe (wzrost terapii przeciropadacz- 
korvej), błędy literowe prowadzące do nieporozumień (wytrzeszcz tętnicy) lub wskazujące na niezrozumienie tekstu oryginalnego (tętnicza/nietętnicza neuropatia niedokrwienna, choroba Lyme'a). Nazewnictwo bywa niespójne (na jednej tylko stronie: neuralgia trójdzielna, nerwoból trójdzielny, nerwoból nerwou trójdzielnego). Występują drobne, ale utrudniające lekturę błędy składu (np. odmienna czcionka polskich znaków diakrytycznych w nagłówkach wielu tabel). Książkę wydano w dwóch tomach w miękkiej oprawie - dla wielu osób taka forma może być niewygodna w codziennym użyciu.

Wspomniane niedociągnięcia nie powinny przesłonić znakomitej treści, czytelnego układu i przemyślanych ilustracji. Polecam tę książkę studentom medycyny, zwłaszcza tym bardziej zainteresowanym naukami neurologicznymi, a także wszystkim lekarzom, którzy opiekują się pacjentami $z$ chorobami układu nerwowego - zwłaszcza lekarzom rodzinnym, internistom, geriatrom, specjalistom w zakresie rehabilitacji i wszystkim tym, którzy w pogoni za szczegółową specjalizacją nie zatracili zdolności do całościowego postrzegania problemów swoich pacjentów.

\section{Woiciech Turai Katedra i Klinika Neurologii, Collegium Medicum UJ w Krakowie}

